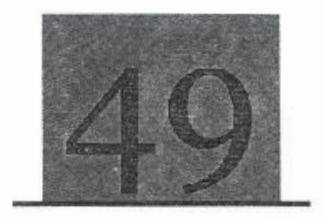

\title{
Protein profile expression of Clarias gariepinus, Heterobranchus bidorsalis and their reciprocal hybrids in southwest Nigeria
}

\author{
Agbebi, O. T. / Sofela, S. O. / Olowofeso, O. /Idowu, A. A.
}

\begin{abstract}
Proper genetic characterization would help in the selection of suitable strains for aquaculture that could lead to production of new varieties of fishes to alleviate the problem of short supply of fast growing quality fish seeds. The study was aimed at analyzing the muscle. protein profiles of Clarias gariepinus, Heterobranchus bidorsalis and their reciprocal hybrids. Sixteen juveniles fish samples (comprising four samples from each mating combinations) artificially propagated and reared for sixteen weeks were analyzed electrophoretically. The separation of the different polypeptides of C. gariepinus, H. bidorsalis and their reciprocal hybrid were carried out using $12 \%$ Sodium dodecyl sulphate polyacrylamide gel electrophoresis (ID SDS-PAGE). The relative concentration of individual protein bands were analyzed using TotalLab ${ }^{\mathrm{TM}} 1 D$ software. The individual protein bands in the electrophoregram were identified in relation to their molecular weights. The gel images obtained after electrophoresis were scored and subjected to cluster analysis. The 1st, 2nd, $3 \mathrm{rd}, 4 \mathrm{th}, 8 \mathrm{th}, 9 \mathrm{th}, 10 \mathrm{th}$, and 11 th bands were detected across all mating combinations. The 5 th band with molecular weight (78.58 KDa) distinguishes C. gariepinus from $\mathrm{H}$. bidorsalis while the 6ith band with molecular weight $(54.41 \mathrm{KDa})$ distinc/s the reciprocal hyrids Clariabranchus from Heteroclarias. The 7 th and 12 th bands distinguished the pure breeds from the hybrids. The 7 th band was present in both hybrids - Clariabranchus $(49.50 \mathrm{KDa})$ and Heteroclarias $(49.77 \mathrm{KDa}$ ) species but absent in the pure breeds while 12 th bands was present in the pure breeds $-C$.gariepimus $(19.92 \mathrm{KDa}$ ) and $\mathrm{H}$. bidorsalis $(20.29 \mathrm{KDa})$ but absent in the hybrids. The cluster analysis shows a high level of genetic similarity among the mating combinations which affirms the already established monophylogenetic relatedness among the species.
\end{abstract}

Keywords: Electrophoregram, protein profile, Claria gariepinus, Heterobranchus bidorsalis.

\section{Introduction}

$\mathrm{A}$ quaculture has been accepted over the world as a means for increasing fish production in a developing country like Nigeria with her immense resources offer tremendous possibilities for fish culture. Catfish family Clariidae is very popular in Nigeria due to its culture characteristic which has endeared it to many fish farmers. Clarias gariepinus and Heterobranchus bidorsalis are species of high aquaculture importance in Southwestern Nigeria. They are widely cultured owing to their high market price, fast growth rate and ability to withstand adverse pond conditions especially low oxygen content (Idodo-Umeh, 2003).

Several efforts from the Government and Private Sector, Universities, Research institutes in Nigeria that have been directed towards increased fish production through various research activities in recent times have yielded positive impacts especially in the area of increased fish seed production through the establishment of fish hatcheries; development of hybrid catfish etc (Idodo-Umeh, 2003). Although, this effort has yielded some positive result, observation on the field has shown that there are problems of Clariid catfishes identification especially hybrids. This can jeopardize the future of aquaculture industry in Nigeria if something is not done quickly (Yisa Olufeagba, 2005). For any successful catfish breeding and genetic improvement program, there is the need for; Identification of the parent stock, Sexing to identify male and female broodstock, Differentiation of reciprocal hybrids from the putative parent stock.

In the past, the identification of fish species was carried out mainly by examining the external morphological characteristics. In the present day, electrophoresis of whole muscle protein, sarcoplasmic proteins, serum proteins, liver proteins, salivary proteins and a number of enzymes often have been used by some researchers as an aid in the species identification of fish (Zaki et al. 2001, Pinero et al. 2001, Yilmaaz et al. 2007, Lamy et al 2008). Sexual dimorphism in electrophoretic patterns of blood serum proteins of a smelt [Hypomesus nipponensis] was investigated (Komagata et al. 1991). 
Most morphological traits are polygenic, quantitative or continuous characters and their expression is influenced by environmental conditions and are therefore not confirmatory enough (Omoniyi and Fagade, 2001). The traditional approach to characterization and evaluation is based on morphological features. However, biochemical analysis of total protein and isozyme markers reveal better diagnostic genetic variations and is usually free from genotype and environment interactions (Torkpo et.al, 2006). Thus, gel electrophoresis has become common tool for studying variations at the genetic level. Therefore, the study aims at analyzing the muscle protein profiles of Clarias gariepinus, Heterobranchus bidorsalis and their reciprocal hybrids using the SDS-PAGE technique to establish the resemblances and differences between the species and their hybrids.

\section{Materials and Methods}

Muscle sample collection. The experimental fish was produce through intergeneric hybridization between C. gariepinus and H. bidorsalis obtained from Hepa Fish Farm, Asero, Abeokuta, Nigeria. The following crosses were carried out for parental cross - C. gariepinus $\times$ C. gariepinus and H. bidorsalis $\times H$. bidorsalis, and hybrids $C$. gariepimis and $H$. bidorsalis-(Clariabranchus) and H. bidorsalis x C. gariepinus (IIeteroclarias). Sixteen juvenile fish samples (comprising four samples from cach mating combinations) were transported live in well open plastic rubber bowls to the Biotechnology laboratory unit of the Animal Breeding and Genctics of the Federal University of Agriculture, Abeokuta. Muscle were isolated from the epiaxial muscle in the region below the cranial to the dorsal fin, above the lateral line of the experimental fish with the aid of a new surgical blade for each species (ElSerafy et al., 2006 and Reedish et al., 2008) after fish killing by medullar transaction (El-Serafy et al., 2006). Fish muscle protein extracts were prepared by quickly homogenizing $100 \mathrm{mg}$ of muscle (on ice) in $1.5 \mathrm{ml} \mathrm{of} \mathrm{urea/thio-}$ urea buffer containing $80 \mathrm{M}$ Urea, $2 \mathrm{M}$ Thiourea, $75 \mathrm{mM}$ DTT, $50 \mathrm{mMTris,} 0.004 \%$ bromphenol blue, pII 6.8 . The extracts were centrifuged in a tube at $10000 \mathrm{~g}$ for $10 \mathrm{~min}$ and stored at $-20^{\circ} \mathrm{C}$ in the deep freezer.

- Sample preparation for SDS-PAGE analysis, Gel staining, Image analysis and Statistical analysis. Protein fractions were centrifuged for 5 minutes at $10,000 \mathrm{x}$ g at room temperature prior the electrophoretic analysis. Samples were loaded into (12.5\% polyacrylamide gel with $3 \%$ stacking gel) $1 \mathrm{~mm} \times 12 \mathrm{~cm} \times 14 \mathrm{~cm}$. First, gel capillary chamber was loaded with a broad range molecular weight standard (BioRad Laboratories, Hercules, (A). Proteins were separated by applying constant voltage of $300 \mathrm{~V}$ for $2 \mathrm{hrs} 30 \mathrm{mins}$ until the dye front reached the bottom of the gel. After electrophoretic separation, gels were stained overnight with gentle agitation on an orbital shaker. Staining buffer contains $(400 \mathrm{ml}$ methanol, $50 \mathrm{ml}$ glacial acetic acid and Coomassic Brilliant Blue G250) and subsequently destained with $10 \%$ acetic acid. Images were digitized and acquired employing a CCD camera (Samsung ES25- Samsung Opto, Electronics Co. Ltd). Raw images were subsequently imported into TotalLab 1D software (Nonlinear Dynamics, Newsacastle upon Tyne, UK) and analyzed (band detection and molecular weight calculations). User defined parameters employed was according to Agbebi et al (2013). The images were scored to compare the degree of similarity of the hybrids with those of pure breeds. The protein banding patterns obtained from electrophoretic profiles were subjected to cluster analysis to show the relationship in their clustering patterns using the Unweighted Pair Group Method with Arithmetic means for phenogram or dendrogram grouping (Sneath and Sokal, 1973) using statistics software PAST (Majolagbe et al., 2012).

Results

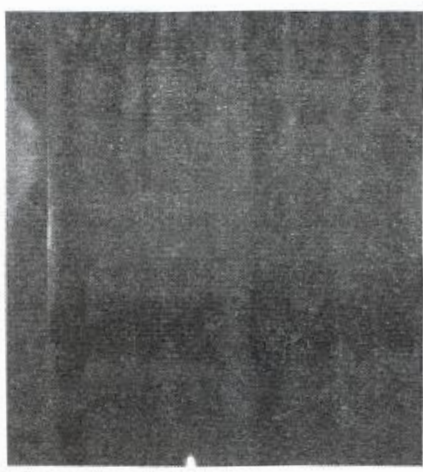

Fig. 1: Raw Image of $12.5 \%$ SDS Whole Muscle Protein of artificially propagated C. gariepinus, $\mathrm{H}$. bidorsalls and their reciprocal hybrids

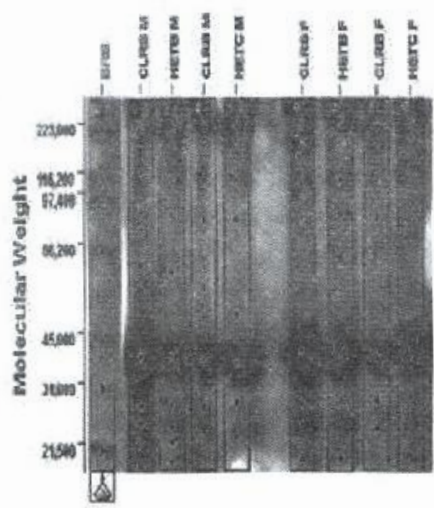

\begin{tabular}{l}
\hline Lane 1 BRS (Bio-range standard) \\
Lane 2 CLRS M C. gariepinus (male) \\
Lane 3 HETB M H. bidorsalis (male) \\
Lane 4 CLRB M Clariobranchus (male) \\
Lane 5 HETC M Hoieroclarias (male) \\
Lane 6 CLRS F C. gariepinus (temale) \\
Lane 7 HETB F H. bidorsalis (female) \\
Lane 8 CLFB F Clariobranchus (temale) \\
Lane 9 HETC F Heterociarias (temale) \\
\hline
\end{tabular}

Fig. 2: Calibrated Image of $12.5 \%$ SDS Whole Muscle Protein of artificially propagated $\mathrm{C}$. gariepinus, $\mathrm{H}$. bidorsalis and their reciprocal hybrids

Figure 2 shows the result of raw image analysis (Figure 1). The blue diamonds denote bands detected and calibrated under the Calibrated Image of $12.5 \%$ SDS Whole Muscle Protein of artificially propagated C. gariepinus, H. bidorsalis and their reciprocal hybrids after analysis of raw image by Total-Lab software. A total of twelve different protein bands were resolved across the entire gel. The $1 \mathrm{st}, 2 \mathrm{nd}, 3 \mathrm{rd}, 4 \mathrm{th}, 8 \mathrm{th}, 9 \mathrm{th}, 10 \mathrm{th}$, and 11 th bands were detected across all mating combinations. The 
average number of protein bands resolved among the pure breeds; $C$. gariepinus and $H$. bidorsalis were eleven and ten respectively in all examined species. In C. gariepinus the 5 th band was present but absent in $H$. bidorsalis. The 12 th band was present in the pure breeds but absent in the hybrids. In the hybrids; Clariabranchus and Heteroclarias the average number of protein bands resolved was ten and nine respectively in all examined species. The 7 th band was present in both hybrids species but absent in the putative parents. The 6th band was present in Clariabranchus species but absent in Heteroclarias species, hence distinguishes the hybrids.

In the male pure breeds, ten protein bands were resolved for both C. gariepinus and H. bidorsatis while the male hybrids Clariabranchus species and Heteroclarias species nine and eight protein bands were resolved respectively. In the female pure breeds, eight and hybrids both resolved seven protein bands. Most female were observed to have less bands compared to male. The males had an average of nine bands while females had eight bands. Although there were sexually dimorphic bands among individual species, no sexually dimorphic band can be satisfactorily reported.

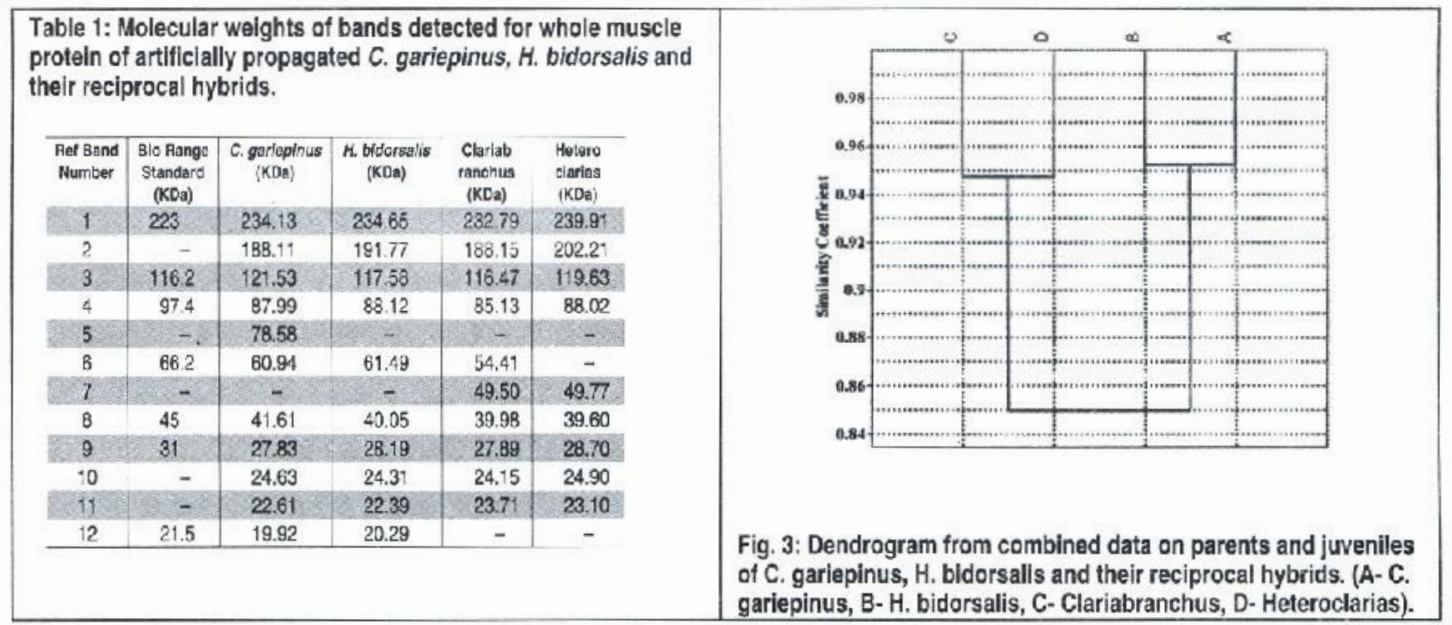

The distinguishing fifth present in C. gariepinus but absent in $H$. bidorsatis had the molecular weight $78.58 \mathrm{KDa}$. The 12th band present in the pure breeds but absent in the hybrids had the molecular weights 19.92 KDa and $20.29 \mathrm{KDa}$ in C. gariepinus and $H$. bidorsalis respectively. The 7 th band present in both hybrids species but absent in the putative parents had the molecular weights $49.50 \mathrm{KDa}$ and $49.77 \mathrm{KDa}$ while the 6th band which distinguishes the hybrids had the molecular weight $54.41 \mathrm{KDa}$.

The dendrogram obtained (Fig. 3) when the data from hybrids and the pure breeds are combined are shown in two major clusters.

\section{Discussion}

A total of twelve protein bands were resolved from the whole muscle protein bands of the clariid species. This varied slightly from the number of Clariid serum protein banding pattern of sixteen and fifteen respectively observed by Akinwande et al. (2012) and Majolagbe et al. (2012) but was similar to thirteen observed by Diyaware et.al. (2011; 2012). This variation in of total number of protein bands resolved in this study and the above authors is as a result of the obvious use of muscle tissue and serum respectively because the structure of blood serum proteins, muscle proteins as well as enzymes in blood and some organs appear to be variable (Kirpichinkove, 1981). The putative species had more bands than the hybrids. This is contrary to research published by most authors. There was also a slight decline of eleven to ten protein bands in the plasma and muscle of Tilapia respectively as observed by El-Serafy et.al (2006).

Zaki, (1996) in the identification of the protein pattern in the resulting hybrid and the pure parental strain of Oreochromis sp using iso-electro focusing method affirmed that banding patterns in electropherograms were found constant in each species and differ characteristically between species. The results reported in the present work indicate species-specific patterns with common bands for all the studicd species as well as specific bands characterizing each species. The whole muscle fraction obtained in this study showed a high number of polymorphic fractions, this proves the close monophylogenetic relationship of the parental genus hence successful hybridization between them. This is in agreement with Akinwande, et al. (2012) on the serum protein pattern in interspecific and intergeneric hybrids of some Clariids. The discriminating protein bands obtained in this study between the pure strains: C. gariepinus and H. bidorsalis was low. Only the 5 th band was present in C. gariepinus but absent in $H$. bidorsalis. This therefore can be used as diagnostic marker for the biochemical identification of the parent stock. The 7 th bands present in the reciprocal hybrids and 12 th bands present in the putative parent stock were the differentiating bands between them, hence can be used as diagnostic protein bands. The distinguishing band between both hybrid combinations is the 6th band in Clariabranchus. Similar result was obtained by Diyaware et al. (2011) where the absence of the 12 th band in the reciprocal hybrid Heteroclarias differentiated it from Clariabranchus.

Sexual dimorphism in electrophoretic patterns of blood serum protcins of a smelt [Hypomesus nipponensis] was investigated (Komagata et al. 1991). They found that in the electrophoretic analyses of blood serum proteins were different in the female and male Hypomesus nipponensis. Although no sexually dimorphic band can be satisfactorily reported, male and female are easily distinguished from one another under field examination after they are about $10 \mathrm{~cm}$ long (Yisa and Olufeagba, 
2005).

The high similarity coefficient (SC) value obtained (Fig. 3) further proves the monophylogeny of the two Clariids$C$. gariepinus and $H$. bidorsalis. The monophyltic relationship between unidentical subfamilies of family Cyprinidae was proved by Hanfling and Brandl (2000) using allozyme clectrophoretic technique. The close relationship between the genera Heterobranchus and the Clarias has been emphasized by Teugels et al. (1990) using morphological and osteological features. According to Teugels ct al. (1991), the species from the subgenus Clarias are more closely related to Heterobranchus than to some other genus of Clariidae. High genetic similaritics were reported in studies carried out for clariids. However, the high SC reported in this study might also imply a low genetic diversity and therefore explains the high difficulty usually experienced in the field identification and differentiation of the hybrids and their parents based on morphometric and meristic data.

\section{Conclusion}

Protcin fingerprinting presents a unique infallible method of fish identification via the protein profiles of the unknown species. This research will serve as a bridge between the existing gaps of information available on the muscle protein profile of $C$. gariepinus, H. bidorsalis and their reciprocal hybrids.

It will enable Aquaculturists to recognize or identify the right species to use in breeding and genetic studies for accurate results and profitability. It will also serve as an important tool in knowing species of eatfish to be stocked in ponds and open water bodies, consequently solving the problem of poor growth performance and the genetic loss of the pure pulative clariid catfishes.

\section{REFERENCES}

Agbebi, O. T., Wick, M. P., Popovski, L. T. (2013). Evaluation of three protein fractions in ycllow-fish perch species (Perca flavescens) using Two extraction buffers: trichluruacetic acid precipitation and rigor buffer. Ife Journal of Seicnec. 15/2: 197-208

Akinwande, A. A., O. A. Fagbenro and O. T. Adebayo (2012). Serum protein pattern in interspecific and intergeneric hybrids of Heterobranchus longifilis, Clarias gariepinus and Clarias anguillaris in sodium dodecyl sulphatepolyacrylamide gel electrophoresis (SDS-PAGE) International Journal of Fishcrics and Aquaculture Vol. 4/10:202 208.

Diyaware, M. Y., Haruna, A. B. , Abubakar, K. A. and Omitngun, G. O. (2011). Serum protein characterization of intergeneric hybrids between $\mathrm{C}$. anguillaris and $\mathrm{H}$. bidorsallis and their hybrids from semi-arid zones of Nigeria. J. Microbiol.Biotech. Res. 1/4: $227-234$.

A. B. Haruna, Abubakar, K. A., Omitogun, G. O. (2012).Serum protein electrophoretic characterization of C. anguillaris, H.bidorsalis and their hybrids from the Northeast Nigeria. J. Microbiol. Biotech. Res. 2/1:70-77.

Idodo-Umeh, G. (2003): Freshwater Fishes of Nigeria (Taxonomy Ecological Noies, Diets and utilization). Benin City: Idodo-Umeh Publishers Ltd. 232.

Kirpichnikov.R.S.(1981).Genetic basis of fish selection. In Fl-Serafy, S. S, Abdel-Hamide, N. H., Awwad, M. H., and Azab, M. S. (2006), Comparative Study Electrophoreic Protein Pattern Characterization of Tilapia Species in the River Nile. Egypt J. Aquat. Biol. \& Fish. 10/2:147-17R.

Komagata, K., Kawarabayashi, S., Kuwabara, R. (1991). Sexual dimorphism in electrophoretic patterns of blood serum proteins in a smelt Hypomesus nipponensis. Suiscn Gakkaishi, Bull. Jap. Soc. Sci. Fish 57, 8, 1599. In Yilmaz M, R.H. Yilmaz, Alas A. (2007). An electrophoretic taxonomic study on serum proteins of Acanthobrama marmid, Leuciscus cephalus, and Chondrastoma regium. EurAsian Journal of BioSciences. 3, 22-27.

Lamy, E, Gonçalo da Costa, Fernando, C. S., Potes, J., Coelho, A. V. \& Baptista, E.. S. (2008). Comparison of electrophoretic protcin profiles from sheep and goat parotid saliva. J. Chem. Ecol. 34:388-397.

Majolagbe, F. A., Awodiran, M. O., and Awopetu, J. (2012). Elcctrophoretic studies of Clarias gariepinus and Heterobranchus bidorsalis and their hybrids. Ife Journal of Science. 14:1, 167.

Omoniyi, I. T. and Fagade, S. O. (1999). Biochcmical variation in muscle protein of two tilapias (Pisccs: Claridae) and their hybrids in a culture system. Biochemical Research Communication. 13/2:161-165.

Pineiro, C, Vazque , J., Marina, A. 1., Barros-Velazquez, J., Gallardo, J. M. (2001). Characterization and partial sequencing of speciesspecific sarcoplasmic polypeptides from commercial hake species by mass spectrometry following two-dimensional electrophoresis. Electrophoresis. 22/8:1545-1552.

Reddish, J. M., St.-Pierre, N., Nichols, A., Green-Church, K. (2008). Proteomic analysis of proleins associated with body mass and length in ycllow perch (Perca flovescens). Proteomics. 2008, 8/2333-2343.

Sneath, P. H. A. and Sokal, R. R. (1973). Numerical Taxonomy. San Francisco: W.H.

Teuguels, G. G., Ozouf-Costz, C. M., Legendre, M., and Parrent, M. (1991), Journal of Fish Biology. 40/1:81-86.

Teuguels, G. G., Der Nayer, B. and Legendre, M. (1990). Zoological Journal of Linnean Society. 98/ 237-257.

Torkpo, E. Y., Danquah, E. Y., Offei, S. K., and Blay, E. T. (2006). Esterase, total protein and seed storage protein diversity in Okra (Abelmochusesculentus L. Moend). West African Journal of Applied Ecology. 9/177-183.

Yilmaz, M., Yilmaz, R. H., Alas, A. (2007). An elcetrophoretic taxonomic study on serum proteins of Acanthobrama marmid, Leuciscus cephalus, and Chondmstoma regium. EurAsian Journal of BioSciences. 3/22-27.

Yisa, M. and Olufeagba, S. O. (2004). An exposition on field identification of clariid catfishes as an important tool in fish breeding and genetics. Proceedings. 19th Annual Conferenec of the Fisheries Society of Nigeria (FISON), Nov, 29.-Dec. 3, Ilorin, Nigeria. 